\title{
Opinions and Thoughts of Undergraduate Students Receiving Sports Education on Ethical Behaviours in Sports.
}

\author{
Mete Şirinkan' ${ }^{1}$ Levent Önal², Cem Şirinkan³ \\ ${ }^{1}$ Bayburt Üniversitesi, Bayburt, Turkey \\ ${ }^{2}$ Atatürk University, Faculty of Sport Science, Erzurum. \\ ${ }^{3}$ Alpaslan Türkeș Üniversitesi, Adana, Turkey
}

\section{Introduction:}

The main purpose of the departments of physical education and sports teaching, sports management, coaching education and recreation, which are trained in the field of sports education, is to educate students with a leader spirit who want to become sports managers in the future. Students who are considering choosing these departments are looking for sports lovers, leaders, responsible, disciplined, high communication skills, and teamwork compliance (www.kariyer.net).

In these departments where sports education is given, students must acquire ethical behaviours by taking courses on some ethical values (fair play, empathy, tolerance, etc.) as well as taking courses on academic knowledge and skills. In general, although there are many courses related to the field in the curriculum, it is seen that the courses related to ethical values are not in sufficient majority. When these courses are created, implemented and reflected in behaviours in education programs, ethical behaviours will set an example for future generations as well. For this purpose, fair play, empathy, tolerance, taking responsibility, sports ethics, etc. It is thought that ethical concepts will minimize conflicts and negative behaviours in the field of sports. If we briefly talk about these concepts;

Fair Play is defined as ethical behaviour as well as honest behaviour. It is the self-sacrificing behaviour of a person in an event, without considering his / her own life, future, family and interests (Aripinar \& Donuk, 2015). It is a phenomenon that cannot be understood within the rules of the game, but where the individual considers the sportive values and the rights are accepted as equal. Therefore, Fair Play should be handled not only as a concept that regulates sports relations but also as a cultural event. It should be considered a way of life. Complying with traffic lights, waiting in line, respecting the rights of others are considered as "Fair Play". First of all, it should be conveyed to people that they should not leave this main principle in family and primary school, in sports and in every moment of life (Gökçe. A.1991. Act. Aripinar,
Study Area: Bayburt, Turkey

Coordinated: $40^{\circ} 15^{\prime} 35^{\prime \prime} \mathrm{N} 40^{\circ} 13^{\prime} 40^{\prime \prime} \mathrm{E}$

Key words: Humanitarian behaviours, Ethics, Fair Play, Empathy.

Donuk, 2015). Behaving tolerantly and having this feeling begins primarily in the individual's family. It develops in the educational process and takes place in the social life or working environment. In the education process, the guidance and planning of teachers and administrators and their tolerance behaviours contribute to the development of children and prepare them for society. Conflict, discussion, violence and all negative behaviours are less common in society when this feature is positively revealed in social communications, business environments, all kinds of activities and interactions. Thus, it provides positive contributions to a more peaceful and happy life of society.

Carrying responsibility is also included in ethical concepts. Many institutional units have responsibilities in order to see better and more peaceful behaviour in sports fields. The point of view of these institutions can cause sports fields to be more fun and joyful. Organizations that have a responsibility in this matter should take the issue seriously. When we look at the duties and responsibilities of those who are responsible (coaches, athletes, managers, media, fans, etc.):

Athletes-

Not objecting to referee decisions

Not to provoke the audiences

Doping and not using drugs

Not to behave in a way that would harm opposing players

Not to exaggerate in winning and losing situations

Togive good behaviour as an example to athletes

Coaches -

- Coping with stress before, during and after the match To have problem-solving skills

Fair dealing with athletes

Being disciplined and clear in decisions

Not being constructive and provocative in their speech

Managers -

Not to interfere with the work of technical teams

Providing solutions to their problems by communicating well with athletes

To conduct research for the financial and moral development 
of the club

- Having constructive communication with other clubs

- Not including unreal news

Media -

- Not reporting without specifying the source of the news

- $\quad$ Not to include news that will provoke club managers, athletes and supporters.

- Creating equal news for all clubs

- To include amateur sports branches in the press and broadcast

- Continuing to support the team in all outcomes

Supporters -

- Not communicating with rival team supporters based on violence

- Gentlemanly hosting the supporters of the opposing team in home competitions

- $\quad$ Not to create a segregation environment among their team supporters

- $\quad$ As a supporter, bad cheers, swearing, violence, etc. avoiding negative behaviors.

There is a special morality when it comes to sports. If it is considered as "a sports event and a sports ethic that organizes it and makes it human beings", as it is often stated, it should be a morality that is given to sports from outside, adapted and applied (Erdemli, 2002).

Among ethical concepts, tolerance is functional in almost every aspect of human life. The concept expresses the behaviour, attitude, which is imprecise and has some flexibility. Tolerance cannot happen by itself, the measure is necessary for this to happen. Under-tolerance can cause disintegration and impair cohesion. Too much tolerance, on the other hand, spoils the structure of the relationship, brings degeneration and eventually disintegration as well. Under normal conditions, everyone is sporty, moral and tolerant. Morality is a collection of virtues whose value is understood when seen in diff icult situations. Because hard times are the best times for the primitive within us to take over.

\section{Methodology:}

Four departments of Atatürk University Faculty of Sport Sciences were included in the study. 55 students from Physical Education and Sports Teaching (35M + 20 F), 65 students from Coaching Education $(50 \mathrm{M}+15 \mathrm{~F}), 45$ students from Sports Management $(35 \mathrm{M}+10 \mathrm{~F})$ and 60 students from Recreation $(35 \mathrm{M}+20 \mathrm{~F})$ participated.

Interview form with 3 options: Yes, No, Unstable:

Q.1 Doyou have enough information about sports ethics?

Q.2 Do you have enough lessons on sports ethics in the education process?

Q.3 Would you like to have classes on sports ethics?

Q.4 Do you believe that sports trainers exhibit ethical behaviour in the profession?

Q.5 Doyou believe that sports trainers exhibit fair play behaviours in your profession?

Q.6 Does fair play behaviour of sports trainers in your field affect their success?

Q.7 Doyou thinkyou can empathize in yourworkspace?
Q.8 Does the empathy competence of sports trainers affect their success?

Q.9 Do sports instructors display tolerant behaviours in your field of the profession?

Q.1oPlease indicate if you have different views on the subject.

\section{Results:}

$87 \%$ of the students stated that there should be more lessons about ethical behaviour in sports education. At the end of their undergraduate education, they stated that most of the sports trainers $(70 \%)$ did not exhibit professional ethical behaviours. Participants stated that the graduate colleagues of the students who received sports education have a low rate $(15 \%)$ in exhibiting Fair Play behaviour. At the same time, it was determined that the rate of empathy was $10 \%$ and the tolerant behaviors were $5 \%$.

Conclusively, humanitarian behaviours (tolerance, fair play, empathy, human rights etc.) should always be the philosophy of sports education, since the human factor is at the forefront in sports education (teaching, coaching, management, recreation etc.).For this purpose, in the training programs of all individuals who will be trained in the field of sports, features such as tolerance, fair play, empathy and human rights as a sports philosophy form the basis of the training programs. The training programs prepared for this purpose will enable the officials, who will raise new generations in the future, to train trainers who are more respectful to human rights. Creating these behaviours before success in the world and in our country will cause both sports experts to serve more efficiently and new athletes or generations to be healthy, moving and exhibiting good behaviours. In addition, this will prevent conflicts, fights and discussions in sportive environments. Sports activities and competitions, which will be held more peacefully, will increase the quality of life of people and will enable the formation of happy and healthy societies.

\section{References:}

Aripinar, E., Donuk, B. (2015): Ethical approaches in sports management and organizations, FAIRPLAY. Pub. by: Ötüken Publications, Istanbul.

Gökçe, A. (1991): Sports Ethics and New Approach to Sport Philosophy (Virtue in Sports: Fair Play). Pub. by: Meya Publishing, Istanbul.

T.R. General Staff, Land Forces Command (2004): Erdemlik in Sports Fair Play, Ankara.

Erdemli, A. (2002): Sports Philosophy with Its Basic Problems. Pub. by: E Publications, Istanbul.

Erdemli, A. (1996): People, Sport and Olympism. Pub. by: Sarmal Publishing House, Istanbul. 